\title{
Epeli's Quest: Essays in Honor of Epeli Hau'ofa
}

The news of Epeli Hau'ofa's passing on the morning of I I January 2009 spread rapidly. It first came to me in the form of a somber weekend phone call from Tarcisius Kabutaulaka, followed shortly by an e-mail from Vijay Naidu, Epeli's longtime colleague at the University of the South Pacific. Tributes soon flooded in from across the great Ocean he loved so much. They spoke of a person who touched many lives, a man open and inclusive in his embrace. They testified to the profound influence of Epeli's ideas, and, perhaps above all, to the inspiration he provided for Oceanians everywhere, including scholars, creative writers, artists, students, and activists. As Ratu Joni Madraiwiwi put it, Epeli Hau'ofa was "this finest Pacific Islander of our times."

It will long be a matter of regret that Epeli was too ill to travel to Honolulu in April 2008 to attend a book launch in his honor. We were eager to host again this towering figure in Pacific studies, to honor the newly published volume of his selected works, We Are the Ocean, and to celebrate his long-standing connections with this part of Oceania. It was, after all, the volcanic grandeur of the island of Hawai' $i$ that inspired Epeli's seminal essay "Our Sea of Islands," versions of which he delivered at the Hilo and Manno a campuses of the University of Hawai' $i$ in the spring of I 993. I sat in the back and off to the side when Epeli delivered the talk to a bushed audience at Mānoa. It was a profound moment for all of us in that crowded room in Burns Hall, and a turning point in the scholarship of the region.

The idea of a collection of short essays to honor Epeli Hau'ofa was enthusiastically embraced by the editorial board of The Contemporary Pacific (TCP). All of us on the journal team have been influenced by his work, and many had interacted with him over the years. Three of Epeli's

The Contemporary Pacific, Volume 22, Number I, IOI-I 23

(C) 2010 by University of Hawai'i Press 
essays ("Our Sea of Islands," "The Ocean in Us," and "Thy Kingdom Come") had been published in The Contemporary Pacific, and many of this journal's articles and dialogue pieces discussed his work at length. At the time of his death, a richly illustrated TCP article by Katherine Higgins about the Red Wave artists at the Oceania Centre for Arts and Culture, founded by Epeli in 1997, was in press. (Late in 2008, the center was renamed the Oceania Centre for Arts, Culture and Pacific Studies.) We wanted to honor the life and work of a fine colleague, as well as document his personal and professional legacy. But in this tribute we did not want to duplicate the material in the Higgins article, or in Geoffrey White's masterful overview in the foreword to We Are the Ocean. (That collection of Epeli's writings is reviewed in this issue, as is Higgins's book about the Red Wave collective, which was also published in 2008.) So we solicited contributions from a range of individuals who knew Epeli well and asked each to reflect on his influence in their personal, scholarly, and creative lives.

The essays that follow are very personal, revealing, and sometimes irreverent. They reflect Epeli's legendary humility as well as his human frailty, his extraordinary capacity to communicate with peoples of diverse backgrounds, and his remarkable ability to encourage and inspire. They demonstrate the widespread influence of his written work and the transformational quality of his ideas. They give us faith that Epeli's legacy lives on in the hearts and minds of prominent artists and intellectuals across Oceania and will, in turn, continue to empower generations to come. As Ratu Joni Madraiwiwi concludes, it is now up to us to continue Epeli's lifelong quest for a liberated, just, and nurturing Oceania.

One warm evening in late January 2009, a large crowd gathered at Hale Halawai, beside Mānoa Stream, to farewell Epeli. Generous quantities of food, drink, and kava were consumed, chants delivered, music played, speeches given, and stories told. More than one person commented that Epeli would have enjoyed the occasion.

I contemplated the profound influence that Epeli's work had had on me, and the privilege of passing on his ideas to students hungry for messages of empowerment. I remembered our conversations in Hawai' $i$, Fiji, and Australia-and forgave him for the occasion at a conference in the Dominican Republic when he initially mistook me for my colleague, anthropologist Geoffrey White! However, the Epeli moment that remains uppermost in my mind came at "Pacific Studies 2000," a conference convened to commemorate the fiftieth anniversary of the Pacific Islands Studies Program 


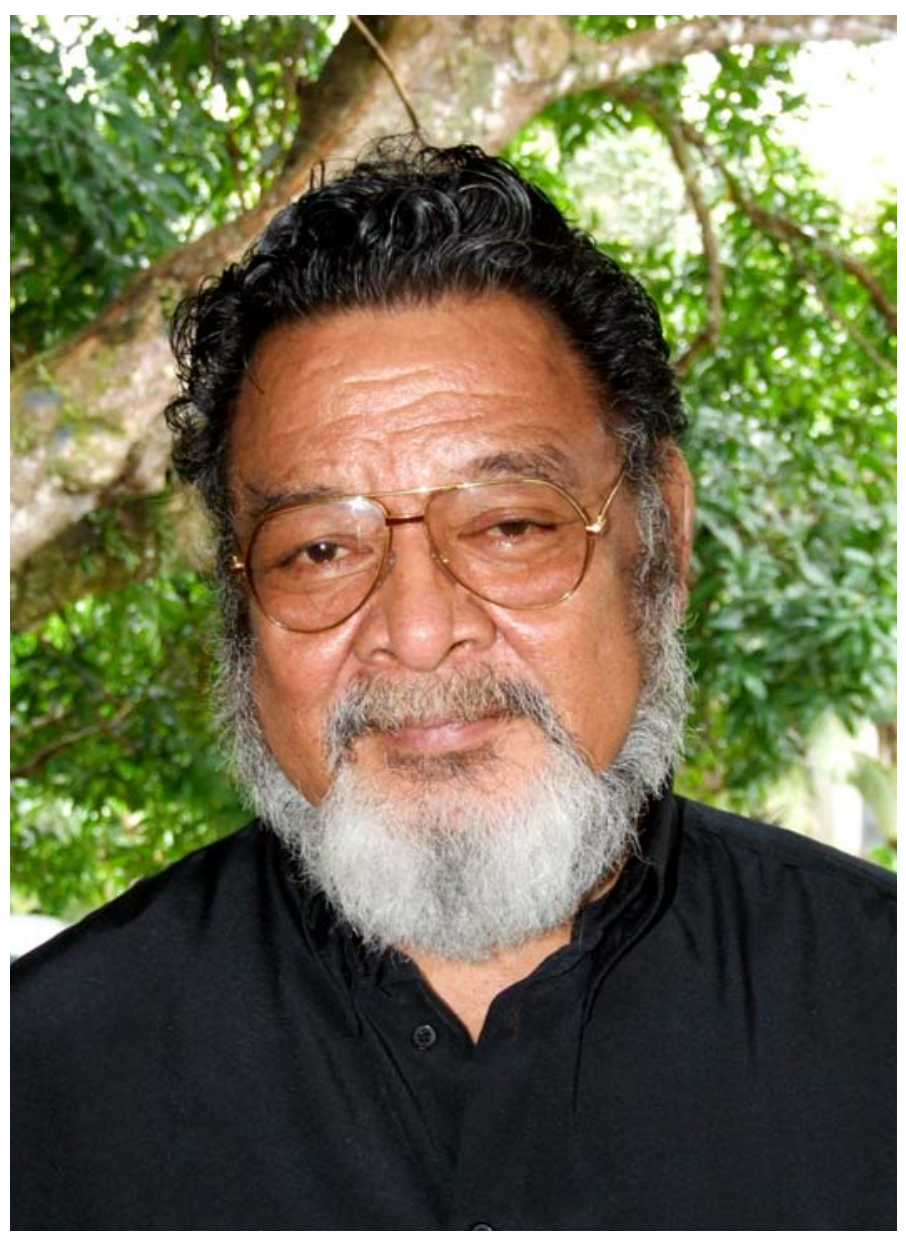

Epeli Hau'ofa at the Oceania Centre for Arts and Culture, University of the South Pacific, Suva, Fiji, 2 I April 2006. Photo by Ann Tarte.

at the University of Hawai i. Konai Thaman set the tone with her keynote address, "Decolonizing Pacific Islands Studies," which provoked animated discussion over the next few days. When it came, Epeli's intervention on the matter was brief and to the point. What Islanders write and say may be bullshit, he said, "but at least it's our bullshit." Well said, Epeli, and Godspeed. 
Muse, Mediator, and Mentor

JONI MADRAIWIWI

In reminiscing about Epeli Hau'ofa following his death, a friend described him as "this finest Pacific Islander of our times." Those who knew him would agree.

Epeli's characteristic modesty would have questioned not only the superlative, but also the term "Pacific Islander." He would have preferred "Oceanian." For Epeli recognized that the vast expanse of sea enveloping us is a pathway rather than a boundary. It has shaped our perspectives and defined us as Island peoples-a factor we have yet to fully appreciate, acknowledge, or understand.

In a very real sense, no one was better equipped to develop that outlook than Epeli. Born in Papua of Tongan missionary parents, he was more fluent in the pidgin of the area than in his mother tongue. Epeli was subsequently to become conversant with several Pacific languages. He completed his secondary schooling in Tonga and Fiji, before venturing for further studies in anthropology in Australia and Canada.

The better part of his working life was spent in Suva, Fiji, at the University of the South Pacific (USP), where he became professor of sociology. If Papua New Guinea was his birthplace, and Tonga where he originated, then Suva was his home. (Indulgent, he would forgive this poetic license, as he actually lived in the wilds of Wainadoi, a small village about thirty minutes drive from Suva.)

The mix of people and cultures in Suva captivated him. He was at ease there because he spoke fluent Fijian and had gone to school at Lelean Memorial School, in Davuilevu, Nausori, near Suva. Epeli once confided that he was not particularly concerned about the xenophobia of the Fiji nationalist Taukei Movement or the fervor of the strict Methodist Sabbatarians, because he felt Suva had become too diverse to succumb to any form of extremism. That was vintage Epeli, ever the optimist.

But as an "outsider" in Papua New Guinea, Tonga, and Fiji, he valued inclusiveness and lived it as well. Epeli also spent a few years in the late I970s as deputy secretary to Tonga's King Tāufa'āhau Tupou IV. A nephew related Epeli's fondness for wearing colorful ankle-length sulus (wraparound skirts), with shirt and a gafigafi (fine mat) around his waist. The mutual affection he shared with the late king was reflected in the latter's indulgence of Epeli's dress in a protocol-conscious court, as well as in Epeli's poignant eulogy to Tupou IV. But Epeli was Tongan only in name; he belonged to all of us. 
Epeli was a larger-than-life figure. His beard and genial visage was reinforced by an ever-present twinkle in his eye. He had a boundless capacity for humor, as well as an understated tongue-in-cheek manner. Epeli never took himself seriously. His satirical novels Tales of the Tikongs and Kisses in the Nederends poke gentle fun at us and our dealings with the world. They also convey Epeli's character in a more personal manner than his academic writings.

It is a matter of regret that he published no further satire, as his minimalist (and on occasion, slothful) inclinations prevailed. These were compounded by a casual attitude that was, at times, infuriating. Epeli was like Tu'imalila (the Galapagos turtle given Tu'i Tonga by Captain Cook); he moved at his own pace.

Epeli's most concrete memorial is the Oceania Centre for Arts and Culture at USP. A whole new generation of artists, performers, and musicians flourished under his benign yet enabling pastoral care. For Epeli, tradition was not the arid, formulaic routine of what had gone before; it was a living, breathing organism of the present day. It drew from the past, yet was neither bound nor limited by it.

But it was his conceptualization of our place in Oceania, both within and beyond, that made Epeli such a towering figure. He inspired us to rethink and broaden our notions of identity in the context of the ocean that links us all-not to jettison our heritage, but to enrich it by exploring common points of reference with others.

In this journey, Barbara, his wife and companion of four decades, traveled with him. It was the affirmation, support, and love between them that enabled Epeli, "this finest Pacific Islander of our times," to give so fulsomely of himself to us. There is no more fitting tribute one may give than to continue Epeli's quest.

An earlier version of this essay was published by Fiji Times Online, I9 January 2009.

\section{The Thing About It Is . .}

TERESIA TEAIWA

To honor Epeli, I want to be elegant. To be true to Epeli, I would be irreverent. To be true to myself, I should be silent. So let me betray myself first. 
Long before I met him in person, Epeli Hau'ofa had touched me intimately and tickled me scandalously-with his pen. I read Tales of the Tikongs and Kisses in the Nederends as an MA student at the University of Hawai'i between 1989 and I990. Like countless others, I marveled at the brilliance of a mind that could conjure up the sidesplittingly familiar caricature of Pacific Islands societies that was Tiko in Tales. Like others privy to the coconut wireless, I was in awe of the wit of a man who could turn the personal experience of a chronic health problem into a wicked satirical allegory of economic, ecological, and cultural neocolonialism in Nederends.

A few years later, in I993, I introduced myself to Epeli while I was passing through the University of the South Pacific. He immediately invited me to give a presentation in his popular school seminar series-even though I was shamefully pregnant-out-of-wedlock and only a lowly $\mathrm{PhD}$ candidate at the University of California, Santa Cruz. Not for him a discrete deferral until the evidence of my fornication had passed, or until a university committee had stamped me fit for professional prostitution. Epeli wasted no time in eventually carving out what was to be my first bona fide academic job... which, I later learned, had displeased some of his colleagues. So it was a matter of some alarm to him when I suggested one year into the contract that I might chuck academic life for a more heroic career in environmental activism. There, in the Head of School's office in the School of Social and Economic Development, for the first time, I witnessed my patron cry. "Why, why?" he wept. "Why do all our good regional staff leave us?" Never mind the technicality that I wasn't "regional" since I carried a US passport; that was the end of the Greenpeace dream for me.

I devoted the next four years, from I995 to 1999, to teaching at Usp, neglecting my $\mathrm{PhD}$, and delighting in my privileged position as a youthful sounding board for Epeli's Oceania Centre for Arts and Culture project. I would see him moved to tears several more times, such as during his fashioning of a modern legend about a people who had had their land mined and someone else's war come to their country, or while listening to Sailasa Tora's and Calvin Rore's haunting musical compositions, and to readings by young writers.

The day came, however, when all that Epeli embodied and represented could no longer compensate for the ways that I was clearly failing to grow at Usp. The next time I broached the subject of a competing job offer, Epeli whispered somberly, "Take it." His lack of protest or resistance to the idea 
disoriented me. But it made it easier to make the fateful decision to move to Aotearoa/New Zealand and take up a job in Pacific studies at Victoria University of Wellington in 2000.

Whenever I went back to Fiji, I made the pilgrimage to the Oceania Centre to see Epeli. I always came away from our ritual three-hour-long talanoas feeling giddy and light-footed. A couple of weeks before Christmas 2008, Epeli mirthfully recounted to me how the medical practitioners who were trying to find out was wrong with him earlier in the year "kept looking in my bum when the problem was now in my peepee." When you've been brought up in the Islands and taught to respect (nay, revere, or better yet, fear) your elders, and then find by some mad roll of heaven's dice that you have become the academic version of a surrogate niece to a man who says things like this to you, a Fijian interjection of surprise seems the only appropriate response: "O sobo."

How could I not think I had a special relationship with Epeli? Well, my fantasy was brought into check very abruptly at his funeral: several hundred other people had obviously thought themselves similarly special to him. Promiscuous bugger.

From vice-chancellor and professoriate, to cleaners, groundskeepers, security guards, and dining hall staff, diplomatic corps members and representatives of international and state bureaucracies, to artists of all varieties (the unemployed, itinerant, commercial, classical, avant garde, and populist): Epeli's funeral was the occasion for a literal (if temporary) burying of class conflict.

From Tongan nationals to diasporic Tongans; from nationalist Fijians to their pro-democracy compatriots; from expatriate Australians, New Zealanders, Americans, Europeans, and Asians to the myriad ethnic minorities within Fiji; from raging heterosexuals to unapologetic queers; from the pious to the iconoclastic: Epeli's funeral was a veritable (if hesitant) ecumenical communion.

No doubt, Epeli had had the most human of failings, but he also had the most profoundly humanist of motivations. On his death, his diverse friends were offered a glimpse of the totality of what he dreamed of, and how he had been living his life striving toward realizing those dreams.

Barack Obama's campaign for the US presidency in 2008 was something that Epeli followed with intense interest and pleasure. I can't remember ever seeing Epeli's eyes glitter more brightly than they did when he spoke of Obama. What I believe appealed to Epeli most about the man whose 
inauguration he was not destined to live to see was Obama's forsaking of ideological dogma for the purpose of building dialogue and community-the audacious pursuit of hope in humanity.

"The thing about it is, our job is to make way for people who are better than us." These were some of the last words Epeli shared with me before I made the big move to leave usp. Ten years later, I am still digesting the implications of such an ego-erasing statement, and what it means to try to apply it in my own practice as a teacher, scholar, and sometime artist.

The idea that Epeli has died still strikes me as a joke told by a comedian with poor timing. I occasionally try to convince myself that he is having a good old laugh up there (or down there) at our expense. If I'm alone when such thoughts visit me, they provide little comfort. I suspect the truly subversive elements of Epeli's legacy are best celebrated not only amid the camaraderie of friends, but also in the company of our perceived enemies.

The thing about it is, elegance and irreverence are perfectly appropriate for celebrating Epeli's life, accomplishments, and even his unfulfilled dreams. But when one is mourning, when one is mourning, when one is mourning ... one welcomes silence.

\section{Conjuring Oceania}

\section{GEOFFREY WHITE}

It is a cliché to say that someone who recently passed away will always be with us. But with Epeli, I actually feel that way. With him, it is easy to hear his voice, to visualize his gentle manner. I feel like he got into my blood. And in Oceania, to talk of blood is to talk of connection, of ancestry, place, history, belonging. Whereas indigenous scholars live and breathe such things in their scholarly work, those of us whose origins are elsewhere (and who are variously defined as guests, travelers or, less benignly, settlers, colonials, and so on) find other ways of reckoning those connections. How could someone who devoted himself to building a sense of community of and for Pacific Islanders, challenging the often-suffocating presence of foreign practices, evoke such a sense of warmth, kindness, and connection? I have no answer, just a feeling of gratitude and loss.

I can't remember when I first met Epeli. It is likely that if I had not come to Hawai'i in 1978 to take up a position at the East-West Center, 
I would not have met him or at least not have had the chance to work with him. But he influenced me long before that. When I was doing the lonely work of writing a dissertation in San Diego based on a year and a half in Solomon Islands I came across an article titled "Anthropology and Pacific Islanders." This was not an article that I had seen cited or heard mentioned by anyone in my department; it was just a chance discovery in the course of perusing recent issues of the journal Oceania while sitting among the scholarly tomes of the research library of the University of California, San Diego. But from the first sentences of that paper, written in the most casual and lucid manner, I found myself drawn in, and invited to reflect about what it was that I was doing and what the field of anthropology was doing at that moment.

And what a moment it was, in the mid-I970s, in the middle of the era when most of the Island nations of the southwest Pacific were gaining independence. Solomon Islands had begun self-government the year I arrived for fieldwork (1975) and would become independent in 1978, the year I received my doctoral degree. Conducting fieldwork at the very beginning of the "postcolonial" period meant that there was much to learn, and much to (re)think regarding the politics and ethics of research-issues that have been central for the discipline and for Pacific studies ever since. Epeli Hau'ofa's reflection on "Anthropology and Pacific Islanders" was like a lightning rod, a connection to charged fields of energy hovering over the contemporary Pacific.

At the time my interest in the article was focused less on its agenda of decolonization than on its critique of the manner in which topics and styles of anthropological representation contributed to the distance between writers and the written. Here is a passage that I quoted in my dissertation:

after decades of anthropological field research in Melanesia we have come up only with pictures of people who fight, compete, trade, pay bride-prices, engage in rituals, invent cargo cults, copulate and sorcerise each other. There is hardly anything in our literature to indicate whether these people have any such sentiments as love, kindness, consideration, altruism and so on. ... We know little about their systems of morality. (Hau'ofa I975, 286)

I liked this passage because it suggested a need for developing a more "experience-near" style of ethnography. For Epeli, articulating this issue was just one step in a longer process of shifting his audience from a global community of academics to Pacific Islanders. In doing so he was perform- 
ing the same kind of empowerment that he urged in his later projects. Although "Anthropology and Pacific Islanders" would now be regarded as a rather minor piece in Epeli Hau'ofa's larger body of work, I mention it here to acknowledge the scope and depth of his career as a scholar and writer.

Looking back at that piece, it is possible to see the seeds of his impending turn toward fiction writing and art. He would later say that the Oceania article was his "farewell" to anthropology (although he asserted that he retained his ethnographic eye as a fiction writer, and resisted characterizations of himself as a trickster figure who simply shape-shifted from one identity to another). For me, on the other hand, it was more a beginning, as I would continue to learn from that article and its author for the next thirty years. Like so many great artists, Epeli never stood still—there was always something new, looking just over the horizon.

Twenty-five years later, when I invited Epeli to Honolulu in 2003 to make a presentation at a summer program designed to introduce American college faculty to Pacific studies, I had put his seminal paper "Our Sea of Islands" on the agenda and expected him to address that paper's argument for "re-imagining" Oceania. Instead, he wanted to talk about his newly founded Oceania Centre for Arts and Culture. In the morning he met with the participants and spoke in a personal and informal fashion about his intellectual career. He seemed to enjoy the give and take. Then in the evening he delivered a public talk in which he played music from the Oceania Centre and displayed some of its artwork in a slide show. Epeli sparkled as he talked about the unlikely process of creating a center that seemed to contravene most of the principles of academic governance, valuing the absence of a program budget, resisting the creation of a degree program, and refusing the standard categories and practices of art and art criticism.

Despite its unorthodox nature, the Oceania Centre has quietly carved out a distinct and productive space for the contemporary arts in and of Oceania. Of course, for Epeli, the center was about more than the arts; it was about fulfillment, empowerment, and a vision for the region. I had a firsthand look one year later, when I stopped over in Nadi, Fiji, in 2004, on my way back from Solomon Islands and phoned Epeli at his home in Suva to say hello. As luck would have it, the very next day he was going to be in Nadi with a group of artists from the center putting up a show in the art gallery of the Sheraton Hotel. So the next day I went to the Sheraton to wait for them. 
When the artists finally pulled up in a van loaded with artwork from the center, it was apparent that this was to be no ordinary Pacific art show. For the next few hours they hung their paintings in a small gallery space, awkwardly shared with other artwork of a more prosaic nature (seascapes, portraits). Epeli hovered around the zone of activity with an air of expectation and gratitude, zooming in to examine this or that, or telling me and others small stories about the artists and their works. His enthusiasm was infectious. In talking to the artists, I learned that one had already sold several pieces to an Australian collector, and some of the others had recently shown their work in a gallery in London. But it did not seem that those successes provided any kind of ultimate validation. Indeed, the Oceania Centre as a whole doesn't seem to seek recognition. It has no Web site, no brochure, no agents; it is just a place to work. All this somehow reflects the understated style of its creator. And yet, so long as the University of the South Pacific chooses to maintain the space, the artistry of the center should continue to grow, like the expanding reach of Oceania. It's a fitting legacy.

Because Epeli lived in Fiji and I in Hawai'i, our encounters were relatively few. Thus I now have the luxury to just imagine that he's still there in Suva, a distant force ... someone who might show up again for one of his magical performances and the simple pleasures that come with seeing an old friend.

\section{The Man from Tiko}

\section{TARCISIUS KABUTAULAKA}

He walks leisurely, almost effortlessly, around campus, clad in a black lavalava that untidily grabs onto the lower end of his shirt. An old bag hangs from his shoulder. A gently graying beard decorates his face. A smoking pipe dangles carelessly from his mouth. He puffs out small bundles of smoke that float for a few seconds, as though in reflection, and then disappear into the humid Suva air. Across his forehead are traces of wrinkles that look like gentle currents in the ocean.

He looks out of place in this academic arena where professors wear trousers and walk around with their head held high, as though they knew everything. He walks with his head slightly bowed. I watch him, wondering what he is thinking. 
He walks into the lecture theater in the same manner, and lumbers to the podium. He is in no hurry. It seems that time cannot outpace him; rather, he drags it along with him. His smoking pipe still hangs from his mouth, held loosely by his lips. He takes it out slowly, almost gracefully, clears his throat, and then drawls a greeting: "Good morning, everyone." His voice is slow, as though the words are fragile and must be spoken with care.

"That is Professor Epeli Hau'ofa," whispers my classmate sitting next to me. I look at the man in front of the lecture theater and then at my classmate. Sensing my confusion, my classmate adds, "He is the author of Tales of the Tikongs." I have never heard of the book, let alone read it. Well, not yet. But, I trust that if anyone should know about books then my classmate is the one. He is the reading type-always has his nose buried in the pages of one book or another.

In the next hour Epeli gives us an overview of his introductory course on Pacific Islands societies, a Foundation Social Science course at the University of the South Pacific. He occasionally peers over the frame of his glasses, perhaps to make sure he hasn't lost us. I diligently write every word he says. That is not difficult because he speaks so slowly, pausing every now and then, as though waiting for us to finish writing. His voice goes up and down like a melody. There are traces of various Pacific Islands accents in his voice, perhaps a testament to his mobility around the region.

I later learn that Epeli was born in Papua New Guinea of Tongan missionary parents, speaks tok pisin, tutored at the University of Papua New Guinea, and did his PhD fieldwork among the Mekeo of PNG's Central Province. That makes me feel at ease in his presence since I feel that he understood those of us from Melanesia, especially Papua New Guinea, Solomon Islands, and Vanuatu. At the university I feel that we, the Melanesians, are sometimes misunderstood by scholars, and I often felt awkward with the descriptions of our societies that I read in books. Epeli is different. Although he is Tongan, he is also a wantok-someone who speaks our language — and understands us, beyond the stereotypes that are sometimes painted of us.

This feeling is reinforced when, years later, I read a paper he presented at a symposium on "The Future of Anthropology in Melanesia" at the forty-sixth congress of the Australian and New Zealand Association for the Advancement of Science (ANZAAS) held in Canberra in January 1975. In that paper he commented on how Melanesian societies and peoples 
were often described in disparaging ways in scholarly writings, especially anthropology, the discipline in which he was, at that time, beginning a career. That was bold. The paper was published in the journal Oceania that year.

But the writings by Epeli that I find most engaging are not his "academic" works, although these are also interesting and informative. Rather, his creative works appeal to me most. Not long after my classmate mentioned Tales of the Tikongs, I borrow a copy from the university library and read it. It is refreshing. The stories are familiar, funny, interesting, and relevant, all rolled into one. I laugh my way through the pages, but at the same time stop and think, "Gosh, that is so true," or "That character is like my uncle." That is how I like my world: full of stories about real and serious issues told in raucous satires. Told in an interesting and engaging way, it doesn't lose the seriousness of the issues. If anything, it makes me remember the seriousness. I later read Kisses in the Nederends and loved it as well.

Later in life, Epeli became a colleague and friend when I joined UsP as junior lecturer at the School of Social and Economic Development, where he was the Head of School. It was then that he wrote his seminal paper, "Our Sea of Islands." After a presentation at the University of Hawai'i, and then later at the USP, some of us were invited to comment on the paper in writing. The collection of resultant essays was put together in volume titled A New Oceania: Rediscovering Our Sea of Islands. I like Epeli's "Our Sea of Islands" piece because it provides Pacific Islanders with alternative ways of thinking about ourselves. However, we must not simply accept the idealistic views of our situations and relationships within the region and among Pacific Islanders but also examine and discuss the complexities. The interactions between peoples in "our sea of islands" are not unproblematic. For instance, differing perspectives and superiority-inferiority complexes among Islanders must be openly discussed and addressed if we are to build, maintain, and strengthen a regional identity connected by the ocean. Also, we need to recognize that focusing on the ocean as the element that connects us immediately marginalizes the millions of people who live inland, in places like the highlands of Papua New Guinea, for whom the ocean has little significance. But these caveats do not take away the fact that Epeli's paper challenges us to think in ways that empower us, rather than marginalize and weaken us. Perhaps Epeli has set the ideals and begun the thinking process. It is for those of us who come after to continue the exploration and discussion. 
While the "Our Sea of Islands" paper is important because it reflects some of Epeli's years of thinking about and interacting with peoples and places of the Pacific Islands region, it is his creative work that I think reflects the man that I first saw strolling around the USP campus, the man who taught me, and whom I later came to know as a colleague and friend.

I was at USP when Epeli started the Oceania Centre for Arts and Culture. It was at this center that Epeli found his calling; he was relaxed and at home. He had founded a place and space where he could help Pacific Islanders explore and develop their talents.

Epeli was the man from Tiko. Like the character Manu in Tales of the Tikongs, Epeli could be funny, serious, relaxed, and accommodating all at the same time. He still challenges us to think differently. Now, whenever I drive past Wainadoi, his home outside Suva, I will look out for the man from Tiko. Perhaps I will see him walking leisurely, almost effortlessly, along the roads of our Pacific Island lives. Moce mada, goodbye, boso levu and wantok. You have left footprints so that we may continue the journey.

\section{Chief of Oceania}

STEVEN EDMUND WINDUO

It is customary in Melanesia to bring betel nuts when we meet others, especially our elders in the community. Betel nut sharing bonds us, strengthens our friendship, opens up conversations, and allows dialogue to take place. Offering betel nut at the first meeting signals a positive, socially productive relationship and a mutually respectful conversation to follow.

Sharing betel nut with Epeli Hau'ofa is the most memorable of my interactions with chiefs in our region. Right after a meeting of the International Council for the Study of Pacific Islands in Nadi, I took the road to Suva to recite poetry with Teresia Teaiwa at the Oceania Centre for Arts and Culture. I planned to meet Epeli Hau'ofa before the recital, which was scheduled later in the evening. I walked across the campus from the USP Lodge at Laucala Bay to the Oceania Centre and waited for him. Epeli came right out to meet me without attending to what he would normally do after arriving at his office. I told him I was happy to read at his center 
that evening and mentioned the experience of looking for betel nuts at the market in Nadi. He smiled as I took them out of my bilum and we sat down to chew.

As we sat there chewing and talking, I could not help thinking about Epeli as a Mekeo chief of Tonga now resident in Fiji. My relationship with Chief Epeli up until that moment was from a distance and through his writing and scholarship. Those have been with me since the day I stumbled onto Mekeo, his I98 I study of inequality and ambivalence in a Papua New Guinean society. I read this book in I984 when I had just started my undergraduate studies at the University of Papua New Guinea. The way it was written stuck with me, and I decided then that I would like to write a similar book about my own society.

This was also the time when I began paying a lot of attention to the craft of writing. I borrowed Chief Epeli's book of short stories, Tales of the Tikongs, from the library, and read it more than once. The book inspired me to write stories that incorporated social or political commentary. I wanted to write in a way that parodied the political elites and the general social landscape in contemporary Papua New Guinea, although I soon discovered that I could do so more effectively through poetry.

Encouraged by reading Tales and writings by other Pacific Islanders, I soon made the transition into the field of literature. Before I had completed my BA degree I had already decided I would make a career as a writer and scholar in academia to help fill the space opened up by the previous generation of writers. In 1987 Chief Epeli published Kisses in the Nederends and reminded us to laugh again, but to think about laughter in a new way. Here was a book that made us realize that making fun of ourselves was a way of expressing more serious thoughts and experiences in an enjoyable way. To get other Papua New Guineans to read Chief Epeli's novel, I published a review of the work in Bikmaus, a journal of the culture and national affairs of Papua New Guinea.

Chief Epeli's influence on my life continued later, particularly through "The Writer as Outsider," an article about working outside of the establishment yet always remaining committed to one's writings and scholarship. As a scholar of indigenous cultures, ideas, and knowledge systems, I saw myself in that role as well.

Meeting the chief of such a school of thought, canonized in his profoundly influential essays "Our Sea of Islands" and "The Ocean in Us," kindled a sense of a new beginning, a renewal of the spirit of relatedness, 
meaning, and promise in what we do as indigenous writers and scholars. It inspired me to move with a more self-assured sense of purpose in advocating indigenous knowledge and ways of knowing in Oceania.

As fate would have it, I was not to meet Chief Epeli Hau'ofa again. A month before his scheduled appearance at the University of Hawai' $i$ to launch We Are the Ocean: Selected Works, David Hanlon gave me a complimentary copy of the book. Chief Epeli never made it to the launching due to the illness that would eventually claim his life. The news of his demise reached me in a spiritual way. I had been reading We Are the Ocean the night before and had the book right in front of me on my desk when I learned that the chief had left us for another shore beyond our reach.

\section{REMEMBERING Boso Leve}

VIJAY NAIDU

Epeli Hau'ofa, whom I fondly called Boso Levu or big boss (although he was never bossy), was my friend, colleague, and mentor at the University of the South Pacific for close to a quarter of a century. We shared the ups and downs of our work in the Sociology Department, as well as in the School of Social and Economic Development, which we each led at different times in the I990s. Our interactions included quiet conversations and heated debates, storytelling and laughter, partying and sumptuous meals. As I reflect on Epeli's influence on my life and work, I feel a deep sense of gratitude and privilege.

By the mid-I980s, I had read Epeli's Corned Beef and Tapioca and Our Crowded Islands as well as Tales of the Tikongs, which impressed me no end. As a development sociologist interested in dependency and underdevelopment theorists, I was taken aback both by the agency Epeli gave local actors (exposing their wiles in the "development game") and by his exposé of the cultural factors weighing heavily on Islanders seeking economic success. These insights were brilliantly packaged with lighthearted humor.

Although Epeli rubbed shoulders with the aristocracy in Tonga and other Pacific Island countries, he firmly identified with ordinary people. He was mindful of the plight of peasants and workers coping with rapidly changing circumstances that were often not of their making. He admired their versatility and resilience and thought deeply about their future. His 
I987 paper "The New South Pacific Society" reinforced my understanding of elites and classes in the region, and noted that ordinary Pacific Islanders were not waiting for leaders to improve their lot but rather were taking matters into their own hands. Delivered originally in Hawai' $i$, his seminal essay "Our Sea of Islands" became the centerpiece of a collection entitled A New Oceania: Rediscovering Our Sea of Islands, edited by Eric Waddell, Epeli, and myself. Published on the twenty-fifth anniversary of the founding of USP, this positive and inclusive vision for all Oceanians remains unmatched to this day.

Epeli came under pressure from all sides when he joined the usp Sociology Department in the mid-r980s. He was expected to rein in the Marxists, who were unpopular with some regional governments, and to fraternize with expatriate "seat warmers" and their Polynesian allies who actively opposed the appointment and promotion of Indo-Fijians. Epeli must have been under a lot of stress, which may have induced the medical problem that brilliantly inspired his Kisses in the Nederends. He also sought light relief by playing cards with secretaries and support staff, joined by a growing number of academic colleagues. The lunchtime card sessions became so popular that there was jostling for seats for the next round of trump.

The manner in which Epeli tackled the challenges he faced as Head of Sociology won him respect among some staff and not others. My own respect for him grew exponentially as he sought to defend colleagues by pointing out the reality of unequal development and increasing inequality in Pacific societies. He revealed a sense of fair play and inclusiveness by befriending Indo-Fijian colleagues while being diplomatic to their opponents.

An incident during the 1985 inaugural conference of Auckland University's Centre for Pacific Studies was also revealing of Epeli's approach. A group of Māori hijacked a session and demanded that all Pākehā leave. When one of my New Zealand colleagues remonstrated with them, a large and intimidating protestor threatened physical violence. My New Zealand colleague called on me to join him in exiting this unpleasant situation. But when I got up to leave with another colleague from Fiji, Epeli grabbed my ankle and told me firmly to sit down. We sat through the session, which was largely a tirade about the conference organizers' insensitivity and lack of respect for the tangata whenua, the people of the land. I have often wondered why Epeli wanted us to remain in the hall. Perhaps he saw it as firsthand exposure to the deep resentment that some Māori felt about 
their subordination in the Pākehā order-or perhaps even as a lesson for us Kai Idia ni Viti (Indo-Fijians).

Epeli and I discussed a number of different topics over the yearswhether academics should be engaged or disengaged with wider society; whether it was chiefly to be silent in troubled times, like after the 1987 coups; the continuation of the monarchy in Tonga; ethnic discrimination in Fiji; the Pacific Islander diaspora and its largely underclass predicament; and the place of creative arts at USP. We agreed on many of these issues, but on some, such as chiefly silence, we agreed to disagree. As I think about these conversations I remember Epeli's calming effect. His wise counsel often provided a sense of balance on matters that agitated me.

At the start of the second Fiji coup in 1987, my colleague Steve Ratuva and I were informed that the military were coming to my place. We had barely arrived at Claire Slatter's house when we heard that the military were on their way there too. Eileen and Morgan Tuimalealicifano kindly sheltered me that night, and on the following day I moved to the usp Laucala Campus, where Epeli and his wife Barbara looked after me for the next few days, even though they were themselves anxious about unfolding events.

Epeli loved his work in the Oceania Centre of Arts and Culture, which he was able to lead to considerable fame in a short period of time and on a shoestring budget. He kept in touch with all kinds of creativity, and in the center itself drew together budding painters, carvers, musicians, dancers, and sculptors. Most of the people involved were not students and staff members but unemployed youth who received a new lease on life. Epeli believed in enmeshing, fusing, and hybridizing different aesthetic traditions. He once said to me that he wanted to encourage Pacific people to do more than just make the same images of the god Tangaloa with his enlarged penis. The center's Red Wave paintings and dance group attained international recognition, much to Epeli's joy.

Some years ago Epeli got very agitated about the "cheeky little Indian woman doctor" at the usp Medical Centre who told him that he would die soon if he didn't change his ways and reduce his weight. But Epeli took to walking along the Suva seawalls every morning, and on Saturdays he would end his walk at the open market before catching the bus back to campus. After he and Barbara relocated to Wainadoi, he exercised on a cycling machine and generally looked like he was in very good shape. Planting "natives" at Wainadoi was both physical activity and a hobby that he engaged with gusto. 
Epeli and Barbara experimented with various projects at their Wainadoi property, including raising free-range chickens, planting hundreds of kava seedlings, and growing native trees. Unfortunately, neither the chickens nor the kava plants survived, their demise variously attributed to viral causes or black magic! However, the trees flourished, enhancing Epeli's vision of an ecological and cultural sanctuary for locals and visitors alike.

Epeli adopted Fiji as his home. He liked the vibrant multicultural environment, warts and all, and made long-term commitments to the place. The vanua of Wainadoi accepted Epeli as one of their own, and he was buried in one of his favorite spots overlooking the valley there. He also loved working at usp because of the space it provided for his creative activities. His long-term service to the university immensely enriched the institution and those of us who worked with him. His mana encompassed usP and rubbed off on all of us. Epeli's contributions will be with us for many generations to come.

\section{Epeli's Owl}

VILSONI HERENIKO

I didn't understand, and I couldn't forgive him.

My first memorable encounter with Epeli Hau'ofa was in I99I. I had taken leave the previous year from the University of the South Pacific, where I was teaching full time, to write my PhD dissertation at the EastWest Center in Hawai'i. During that time I wrote like a madman, driven by the knowledge that I had only one year in which to complete my work.

Every few weeks I sent drafts to my usp supervisor-a white American who had come to Fiji via South Africa-only to be met with a deafening silence. But given the distance, I was at a loss as to what to do. After I got back to USP, I tried to have my supervisor replaced. The university asked Hau'ofa to fill the role. At the time, he was one of very few Pacific Islanders at the university who had PhDs, and I admired him. Hau'ofa refused, saying he wasn't qualified because he didn't have a formal degree in theater, and besides, he was not in the Department of Literature and Language where I was working on my degree.

Hau'ofa's response devastated me. I wondered how a Pacific Islander with a doctorate in anthropology from the Australian National University could truly believe that an American with a master's degree in English, 
who had never lived in the Pacific outside Suva, could have more credibility and knowledge about my topic, clowning and comedy in Polynesia.

Because of Hau'ofa's refusal, all my internal and external examiners were non-Pacific Islanders. I was therefore very surprised when the verdict from my external examiners, one in England, the other in the United States, was to accept my dissertation without any need for revision. I felt vindicated, but did not forget that Hau'ofa hadn't been there for me in my hour of need.

In I993, two years after I had been hired by the University of Hawai' $\mathrm{i}$ and was back in Fiji for a visit, I found myself in Epeli's home. After a few glasses of red wine, I told Epeli how I felt about his decision in I99I. His wife Barbara heard the two of us arguing, but wisely didn't intervene. Epeli still stuck to his view that he had done the right thing, and I left that evening with my feelings of hurt unresolved.

I met Epeli many times over the course of the next sixteen years, in Fiji, Honolulu, New Zealand, and Australia. I invited him to my home in Honolulu several times, and he invited me to his home in Fiji several times as well. During my last visit to his home in the bush at Wainadoi, we hiked the winding trails of a hill nearby, and he showed me trees he had planted with his own hands. He pointed to a grassy hill and said that his dream for the future was to create a safe haven on his property for artists from around Oceania, where they could create new music, write new plays, compose poetry, sing, dance, and tell stories. Later he took me down to a stream that flowed by a thick wooden grove and said that he could imagine the artists swimming in its cool waters and laughing. I could imagine that too.

Later in the day, Epeli and I joined a gathering of the artists from the Oceania Centre at a sandy beach in Deuba, a suburb of Suva, for a picnic. After lunch, I told the students the story of my draft screenplay on Fiji titled "Hibiscus," a film in which I was hoping to involve them. It was a beautiful day, and my favorite memory of that picnic was Epeli sitting with his legs stretched, smoking tobacco, surrounded by impressionable young people who adored him.

On reflection, I suppose the artists at the picnic must have found it inspiring to have two Pacific Islander professors, a Tongan and a Rotuman, laughing, joking, and sharing food with them at the beach. By this time, Epeli's work and mine had been validated in academia, and we had become fearless in our advocacy of indigenous ways of learning and knowing. In spite of our Western training, both of us had been able to free 
ourselves from the shackles of Western academic practices that marginalized traditional wisdom and worldviews.

For three weeks in late 2008 -early 2009 , I was again in Fiji. Toward the end of my time in Suva, I heard that Epeli was very ill and I went to the hospital to see him. I asked Epeli's wife Barbara if I could spend a few moments by his bed and pray for him.

I stared at Epeli in silence. A white sheet covered his body; an oxygen mask covered his face. Epeli was breathing heavily, and his legs were twitching involuntarily underneath the sheet. How could this happen to the man who had written "Our Sea of Islands" and single-handedly changed the course of Pacific studies? How could this happen to the talented author of Tales of the Tikongs and Kisses in the Nederends? Both of these fictional works drew heavily from Polynesian traditions of clowning and comedy, the topic of my dissertation, confirming my belief that Epeli had been more than qualified to be my supervisor in I99I.

Memories flooded my mind as I stood there staring at Epeli. I remembered his helpful suggestion, after a colleague had rattled me by criticizing me in public, to acquire a thick skin for myself. Or the time he quietly advised me not to pay heed to the accusations of an elderly professor who, he said, "was losing his marbles."

But I found it difficult to pray. To whom should I pray? Somehow Jesus didn't seem the right god for Epeli, a man born to missionary parents, but no longer a practicing Christian. I too had become disillusioned with the Christian religion, and seriously doubted the existence of heaven and hell. Should I pray then to the ancient gods? To Tagaloa, perhaps?

The following morning, as I prepared to head for Nadi in order to fly back to Honolulu, I learned that the western part of Viti Levu was under a flood watch. The heavens had opened up and the ancient gods were pouring torrents of rain on Sigatoka and Nadi towns. I had to drive through flooded roads and bridges in a desperate search to find shelter before nightfall.

When I finally reached my niece's home in Nadi, my brother and a sister were there. We sat down to talk. Then I saw, right at eye level, a huge brown bird flying toward me. As it drew nearer, I realized it was an owl. My sister and brother could also see the owl as it flapped its wings gracefully and then flew higher and away into the distance. We stared at each other. My sister asked: "Who is it?"

As soon as I got back to Honolulu, I found an e-mail message informing me of Professor Hau'ofa's death. 
Ancient Polynesians believed the heavens wept when great men died. Were the heavy rains and accompanying floods intended to mark the transition of this extraordinary human being to another reality? Polynesians also believed that when an owl appeared in an unlikely circumstance, it was to announce the death of a loved one. But I didn't feel worthy of Epeli's owl, and wondered why it would fly all the way from Suva, battle with the raging rains and devastating floods, invade the city of Nadi, and enter my angle of vision, to say farewell to me.

Some weeks later, Ty Tengan, an associate professor at the University of Hawai'i, invited me to talk to his class about Hau'ofa's work, and I told them this story. After the class, Ty wrote me an e-mail in which he referred to the owl's flight as a spiritual resolution to my repressed anger toward Epeli. He suggested that it was Epeli's way of saying that all was well between us-not in words, but in symbolic language befitting his persona. Ty's perceptive remark brought tears to my eyes. With the tears, finally, came forgiveness. And understanding.

I realized that, had the $\mathrm{PhD}$ episode happened in 2009, Epeli would have privileged experiential and indigenous knowledge over Western academic credentials and disciplinary boundaries. In fact, when Epeli became director of the Oceania Centre in 1997 he insisted that if creativity and contemporary Pacific art were to thrive, they must be free of university constraints. His own departure from academic life and his deliberate choice to live in a green jungle instead of a concrete one was his way of saying that, at the end of the day, what matters most is a life lived in harmony with the land and sea, and with the rest of nature and humanity.

Farewell, Epeli. You have touched my life more deeply, and more personally, than you could have ever imagined.

\section{References}

Hau'ofa, Epeli

I975 Anthropology and Pacific Islanders. Oceania 45:283-289. Reprinted in Hau'ofa 2008a, 3-10.

I977 Our Crowded Islands. Suva: Institute of Pacific Studies, University of the South Pacific.

I979 Corned Beef and Tapioca: A Report on the Food Distribution Systems in Tonga. Development Studies Centre Monograph 19. Canberra and Suva: The Australian National University in association with the Centre for Applied Studies in Development, University of the South Pacific. 
I98 I Mekeo: Inequality and Ambivalence in a Village Society. Canberra: The Australian National University Press.

I983 Tales of the Tikongs. Auckland: Longman Paul. Reprinted by University of Hawai'i Press, Honolulu (I994).

I987a Kisses in the Nederends. Auckland: Penguin Books. Reprinted by University of Hawai'i Press, Honolulu (I995).

I987b The New South Pacific Society: Integration and Independence. In Class and Culture in the South Pacific, edited by Antony Hooper and others, I-I 2. Auckland: Centre for Pacific Studies, University of Auckland; Suva: Institute of Pacific Studies, University of the South Pacific (I987). Reprinted in Hau'ofa 2008 a, I I-23.

I993 Our Sea of Islands. In A New Oceania: Rediscovering Our Sea of Islands, edited by Vijay Naidu, Eric Waddell, and Epeli Hau'ofa, 2-I6. Suva: School of Social and Economic Development, The University of the South Pacific. Reprinted in The Contemporary Pacific 6:I47-I6I (I994), and in Hau'ofa 2008a, 27-40.

I994 Thy Kingdom Come: The Democratization of Aristocratic Tonga. The Contemporary Pacific 6:4I4-428.

I997 The Ocean in Us. Dreadlocks in Oceania I:I24-I48. Reprinted in The Contemporary Pacific I0:39I-4Io (I998) and in Hau'ofa 2008a, 4I59.

2008a We Are the Ocean: Selected Works. Honolulu: University of Hawai'i Press.

2008b The Writer as an Outsider. In Hau'ofa 2008a, 97-ro9.

2008c His Majesty King Taufa'ahau Tupou IV: An Appreciation. In Hau'ofa 2008, I72-I79.

Higgins, Katherine

2009 The Red Wave Collective: The Process of Creating Art at the Oceania Centre for Arts and Culture. The Contemporary Pacific 21:35-70.

Thaman, Konai Helu

2003 Decolonizing Pacific Studies: Indigenous Perspectives, Knowledge, and Wisdom in Higher Education. The Contemporary Pacific I 5:I-I7.

Waddell, Eric, Vijay Naidu, and Epeli Hau'ofa, editors

I993 A New Oceania: Rediscovering Our Sea of Islands. Suva: School of Social and Economic Development, University of the South Pacific.

White, Geoffrey

2008 Foreword. In Hau'ofa 2008a, ix-xx. 